sciendo

10.2478/abcsj-2020-0004

\title{
Alchemical Cities, Apocalyptic Cities: The City as an Exponent of Magical Realism and Ideology in Angela Carter's Novels
}

\author{
NINA MUŽDEKA \\ University of Novi Sad, Serbia
}

\begin{abstract}
Reality in Angela Carter's magical realist novels is depicted through the deployment of numerous picturesque details that correspond to the readers' experiential reality, differentiating such a world from non-realist forms. Though the magical realist fictional world is akin to the one outside of the fictional reality, the mode's strategy still differs from that of traditional realism due to the absence of a purely mimetic role. Initially serving to establish what Roland Barthes termed l'effet de reel (the effect of reality), the city in Carter's novels is indeed constructed according to the principles of magical realism and creates plausible links between textual and extratextual realities. Further inclusion of magical, uncanny elements into such a world, in one respect, leads to the creation of excentric spaces that promote the position of the marginalized Other and allow alternative outlooks on life to gain prominence. A hybrid reality that is the ultimate result of the coexistence of the normal and the uncanny leads to the subversion of what Carter saw as patriarchal stereotypes, primarily due to the fact that it problematizes and ultimately negates their very foundation. In other words, if we cannot agree on the criteria for what is real, how can we trust the ultimate authority of any other criteria? The city in Carter's novels thus acts as a suitable literary venue for revealing the author's ideological position.
\end{abstract}

Keywords: Angela Carter, magical realism, the city, mimetic reality, narrative construct, hybrid reality, ex-centric space

In 1969, Angela Carter won the Somerset Maugham Award for the novel Several Perceptions, published the previous year. According to the stipulations of the award, the proceedings of 500 pounds had to be spent on 
foreign travel so that young writers "can enrich their work by gaining experience of foreign countries" ("The Somerset Maugham Award"). For Angela Carter, this removal from the familiar surroundings was a liberating and formative experience, which changed her outlook on the world for good - but, most importantly, on herself. Carter became, in her own words, "a connoisseur of cities, of American, Asiatic and even European cities," which is a true feat "for someone who had, previously, never been further than Dublin, Eire" (Carter, "My Maugham Award" 203-204). During the two years she spent in Japan, Carter became "radicalized" as a woman and as a feminist, having explored the stereotypes of gender, but also of sexual, cultural, and national identity. For her, the space was never just a space, but an arena heavily imbued with socially and culturally defined constructs of identity - or, as Carter would say, myths. Therefore, the city in Carter's novels - in her post-1984 magical-realist novels, as well as in those written before 1984 - is never just a mimetic representation of the space and its topography. Instead, it takes on diverse morphological features that help represent the author's ideological position and her tireless work on debunking perceived social and cultural myths.

I contend that the construction of the city can be read as an exponent of magical realism in five of Carter's novels that, to a lesser or greater extent, exhibit the formal and ideological features of the said narrative mode: The Magic Toyshop (1967), The Infernal Desire Machines of Dr Hoffman (1972), The Passion of New Eve (1977), Nights at the Circus (1984), and Wise Children (1991). Even though the scholars that analyzed Carter's works (Sage, 1994; Gamble, 2001; Day, 1998) generally agree that her magical realist phase - in which she most consistently expressed her ideological position and her artistic, social, cultural, and political engagement - officially started with her 1984 novel, Nights at the Circus, and continued with her last novel, Wise Children, it is true that the features of magical realism, to a different extent, can be found in her previous novels as well - especially so in The Magic Toyshop, The Infernal Desire Machines of Dr Hoffman, and The Passion of New Eve (Muždeka 24). The elements of magical realism - as analyzed by Bowers (2004), Faris (1995; 2004), Hegerfeldt (2002; 
2005), Schroeder (2004), and Wilson (1995) - allowed her to construct worlds that are at the same time familiar and uncanny, soothing and frightening - but never too strange to be written off as fantastic. Magical or uncanny elements in magical realist novels cannot be "recontextualized" or explained away as a dream, hallucination, metaphor or a figure of speech, but need to be accepted, through suspension of disbelief, as part of the fictional textual world (Hegerfeldt, "Contentious Contributions" 66). Speaking of her short stories, Carter emphasized the fact that they are not dreams to be discounted as unreal escapism when a materiality of symbols they incorporate, "a materiality to imaginative life and imaginative experience" (Haffenden 85), have to be taken quite seriously. This is applicable to Carter's novels as well, since the city she constructs using narrative means represents the imaginative venue for fighting social injustices and patriarchal stereotypes in the world that is all too real. In this, she echoes the concerns of both postmodernism and postmodernist feminism (Pitchford, 2002; Hutcheon, 1988), but also the Bakhtinian carnivalesque (Robinson, 1991) and its disruptive function. It is precisely at the cross-section of these theoretical frameworks that my analysis of the construction of the city as a vehicle for Carter's ideological engagement in her magical realist novels is centred. I aim to show how Carter constructs the city through the disruptive juxtaposition of realist and magical elements, emphasizing violence as one of the markers of socio-cultural, economic and political stratification of the society. Also, I intend to show how such juxtaposition is both facilitated by, and predicated upon, the deployment of ex-centric spaces, and how this process results in the creation of a specific hybrid reality that qualitatively and programmatically differs from that of mimetic realism. Consequently, I aim to contest the idea that the author's ultimate purpose in the use of magical realism is the narrative creation of utopian spaces, since her ideological engagement is founded on the belief that, within the current myth-based society, utopian spaces are small, scarce, and transient and, as such, insufficient to warrant any thought of ceasing the fight against patriarchy and its misconceptions. 
The City as Barthes's Effet de Réel

Magical realist novels, at their very opening, can often be mistaken for traditional realist novels, primarily due to the fact that the characters and events are initially positioned within real time and space coordinates. The city, in Carter's novels, serves this purpose of anchoring the textual world in the shared everyday reality. However, after the atmosphere of the common, familiar world is thus established, and a reality effect created, it is all the more quickly destabilized and destructed by the introduction of such elements that have no place in everyday reality, as readers know it. Thus, Carter's cities appear to be realistic and to mimic the readers' experiential world, but are simultaneously filled with fantastic and magical elements that subvert their reality - albeit not enough to question the veracity of the author's agenda.

Perhaps the best example of such a strategy is found in the first part of Carter's Nights at the Circus, titled "London," where the protagonist Fevvers starts narrating her life history from the moment she "first saw light of day right here in smoky old London" (Carter, Nights 3). Immediately after she introduces herself as "Cockney Venus," Fevvers shatters the illusion of realism "due to the unusual circumstances in which I come ashore - for I never docked via what you might call the normal channels, sir, oh, dear me, no; but, just like Helen of Troy, was hatched" (Carter, Nights 3, original italics). Her mentioning of hatching contends and subverts the illusion of realistic mode that was previously established via her cockney accent and the references to London (shared space) and Greek mythology (shared knowledge). As Anne Hegerfeldt writes in Lies that Tell the Truth: Magic Realism Seen through Contemporary Fiction from Britain, the constructed plausible city at the beginning of the magical realist novels features "typical realist markers doubling the extratextual world" (77) and invokes the conventions of realistic fiction.

Wendy B. Faris considers the tendency to set the action of the novels in rural parts to be one of the defining aspects of magical realism, which she called a kind of "postmodern pastoralism" ("Scheherazade's Children" 182). Carter's magical realist novels, however, defy this rule. The 
very first sentence of Carter's Wise Children also sets the novel in London and hints at the everyday normalcy shared by the reader through references to other extratextual real-life cities, namely Budapest, New York, and Paris. The common denominator here is the geographical layout - just like London, these cities are divided into two parts by a river, and this binary division becomes not just the trait of Carter's cities, but also the literalization of the general dichotomy she sees as permeating our social and cultural realities. Division into Buda and Pest, Manhattan and Brooklyn, rive gauche and rive droite serves the purpose of drawing the demarcation line between the rich and the poor, the privileged and the underprivileged, the legitimate and the illegitimate, the recognized and the shunned, the clean and the unclean, the center and the margin. The city in Carter's novels thus can often be read as a map of distribution of the center versus the marginalized Others, of the power, authority and authorship versus the powerlessness and lack of authority and authorship.

In Carter's novel, The Magic Toyshop, the author also uses one specific part of the city - South London - to show the stark socioeconomic mapping of the city. The atmosphere of Uncle Philip's house, into which Melanie moves after the death of her parents, is depicted in such a way as to present a mixture of the mutually similar conventions of the Gothic genre and magical realism. The protagonist's move from the house made of "red brick, with Edwardian gables, standing by itself in an acre or two of its own grounds" smelling of "lavender furniture polish and money," "with a bedroom each and several to spare" (Carter, The Magic Toyshop 7) into the city house above a toyshop, resembling a dark cave, represents the transition from the safe world of parental bourgeois home into an insecure world of a socially and financially lower class that signals the veritable extra-textual socio-economic foundation of the novel.

Speaking of Wise Children, Carter touches upon the manner of representing the city, especially London, not only in her fiction, but also in the fiction of other contemporary British authors:

Everybody's writing about London now, and I think it's because we find ourselves at this very crucial moment where we see London changing so drastically all around us. The city I grew up in is gone, and 
when I turned fifty last year I decided I wanted to preserve the London I remember. (Bradfield 91)

This sentiment is echoed by Dora Chance, the narrator of Wise Children:

You can see for miles, out of this window. You can see right across the river. There's Westminster Abbey, see? Flying the St George's cross, today. St Paul's, the single breast. Big Ben, winking its golden eye. Not much else familiar, these days. This is about the time that comes in every century when they reach out for all that they can grab of dear old London, and pull it down. Then they build it up again, like London Bridge in the nursery rhyme, goodbye, hello, but it's never the same. (Carter, Wise Children 3)

Carter is not alone in exhibiting this interest: as Sebastian Groes noted in The Making of London, the city "has become the source and subject of an intense and ferocious imaginative energy since the mid-1970s," to such an extent that the literary scene in the last quarter of the $20^{\text {th }}$ century kept seeing "a body of exceptional work by writers who have unconditionally committed their writing to chronicling the many lives of London" (251). These contemporary writers have "persistently voiced concern about the radical changes that the face of London has undergone, whilst expressing their fury at the various forms of injustice witnessed by the city and its inhabitants" (Groes 251).

Carter, however, also depicts non-European cities, finding the signs of the times changing in them as well. In The Infernal Desire Machines of Dr Hoffman, the usual everyday reality of an unspecified South American city in which the narrator grew up, depicted at the beginning of the novel, is soon replaced by the chaos of literalized fantasies of the city's residents during Dr Hoffman's siege. The real world and the magical world are clearly separated - the city of Desiderio's youth was the real city until the siege began. It is only at the onset of the siege that the two worlds are merged, and the readers are faced with the portrayal of the problematized boundaries between what is real and what is not. The city becomes filled with mirages intended to drive the residents mad, for nothing in the city is what it seems to be - sugar tastes salty, pineapples are the colour and texture of strawberries, and blue doors turn green overnight. Here, too, Carter's ideological engagement is clear, for even such a fantastic city 
exhibits the most socially, politically, and culturally relevant traits of the real world. The city - intended by Carter to be read as "an inventory of imaginary cities" (Sage, "The Savage Sideshow" 56) - is depicted as having been "prosperous," "solid, drab, yet not unfriendly," but it is also heavily gendered, being perceived by the narrator Desiderio as "thickly, obtusely masculine" (Carter, Infernal Desire 3). Desiderio goes on to explain the distinction between some cities which are "women and must be loved" and others which "are men and can only be admired or bargained with" (Carter, Infernal Desire 3), perpetuating the traditional stereotypes of female and male identities. Furthermore, the unnamed city Desiderio depicts is striving to ignore its undeniable colonial past, at the same time doing its best to ignore its indigenous residents:

The city was built on a tidal river and the slums and the area around the docks still pullulated with blacks, browns and Orientals who lived in a picturesque squalor the city fathers in their veranda'd suburbs contrived to ignore ... The word "indigenous" was unmentionable. Yet some of the buildings, dating from the colonial period, were impressive - the Cathedral; the Opera House; stone memorials of a past to which few, if any, of us had contributed though, since I was of Indian extraction, I suffered the ironic knowledge that my forefathers had anointed the foundations of the state with a good deal of their blood. (Carter, Infernal Desire 16)

To the repertoire of diversifying concepts, such as geographical positioning, gender, class, and affluence, Carter now adds ethnicity, nation, and race, which were relevant in the city's colonial past and remain relevant - though ignored and feared - in the city's anxious present. Without explicitly saying so, the author invokes images of white colonizers, forced coloured labourers, blood, and sacrifice to procure riches for the select minority in the position of power, reinforcing the narrative of victimization and marginalization. Carter uses a similar approach in Wise Children when inscribing British colonial history in the geography of cities and towns, thus constructing Englishness as national identity.

In The Passion of the New Eve, Evelyn starts off from London and New York before he finds himself in a range of alternative fictional communities. The novel opens with the last night Evelyn is spending in 
England: "The last night I spent in London, I took some girl or other to the movies..." (5). Subsequently, he finds himself in apocalyptic New York, the rat-infested city engulfed in "a lurid, Gothic darkness," again ripe with poverty and social inequalities: "I was astonished to see so many beggars in the rank, disordered street, where crones and drunkards disputed with the rats for possession of the choicest morsels of garbage" (Carter, Passion 11). The destruction of the city at the hands of "Blacks" and "Women" exaggerates racial and gender stratification and turns New York into "nothing but a gigantic metaphor for death" (Carter, Passion 15). The megapolis's cityscape is devoid of all topographic features. Instead, Evelyn focuses on the atmosphere of gloom, decay and distrust, and his own feelings, making this the portrayal of the city as "the state of mind" (Stewart 480). One of the alternative communities, an underground matriarchal city, called Beulah, is also depicted in a highly gendered manner, similar to the city in The Infernal Desire Machines of $\mathrm{Dr}$ Hoffman. However, this supposedly feminine space that asserts and celebrates "the great female principle" is depicted by Carter as being "less an escape than a confirmation of patriarchy" (Day 114).

\section{The City and Violence}

Violence constitutes an important element of the narrative construction of the city in Carter's novels. Within the city walls, territorially speaking, violence is not equally distributed - hence, it serves to underline the perceived socio-economic and cultural differences among the residents of the individual parts of the city:

Once upon a time, you could make a crude distinction, thus: the rich lived amidst pleasant verdure in the North speedily whisked to exclusive shopping by abundant public transport while the poor eked out miserable existences in the South in circumstances of urban deprivation condemned to wait for hours at windswept bus-stops while sounds of marital violence, breaking glass and drunken song echoed around and it was cold and dark and smelled of fish and chips. (Carter, Wise Children 1)

Violence is not just an act of aggression but, seen as being inextricably linked to money, class and culture, an element of cultural, social, and 
economic identity of the city. As Pitchford states, "the structures of money and power are built into the city's fabric" (52), and the same applies to violence. It emphasizes the fact that the river Thames is not just the watershed in terms of geography - as a "great wet wound" (Carter, Expletives 120), it makes all the difference between cozy family life, on one hand, and the insecure life filled with fights and beatings, on the other. Carter uses violence in the city to unmask the conventions forming the foundation not only of male and female relationships, but also of the widely accepted notions of identity, in general. The topic of violence is frequently inseparable from the topic of marriage, as in the above example from Wise Children. Although the beginning of the sentence invokes fairy tales, there is nothing fairy-tale like in the harsh social and economic realities of the city portrayed in the subsequent text. Furthermore, Carter posits that violence is not a matter of geography, but rather a matter of gender. Violence suffered by women transgresses the boundaries of white Western civilization, as can be seen in Carter's The Infernal Desire Machines of Dr Hoffman. The women in the African community are victims of sexual mutilation whereas in the centaur community they are humiliated and degraded, which allows Carter "to underline the point that oppression of women is not merely a white European perversion" (Day 82).

The city in The Desire Machines of Dr Hoffman was made unsafe, as part of waging the campaign against human reason, to the extent that "statistics for burglary, arson, robbery with violence and rape rose to astronomical heights" (2). Similarly, New York in The Passion of New Eve is depicted as "an alchemy city," the representative of the world in which "the age of reason is over" (13). In lieu of reason, the city is ruled by the chaos that takes on progressively all the more serious and violent forms, until finally, the entire city is enshrouded in the atmosphere of the apocalypse. This apocalypse reaches the protagonist, Evelyn, as a distant echo of the events taking place on the periphery of the worlds in which he finds himself. The membrane separating the unreal worlds of isolated communities from the real world experiencing the apocalypse proves to be selective and semi-porous, to such an extent that Evelyn is not always informed about what occurs in the "real" world. However, the communities through which Evelyn moves, first as a man and then as a 
woman, do not belong to the age of reason. Instead, they obey their own authentic rules of existence, their own unique, alternative reasoning:

Ever since the interrupted continuum I refer to as myself had left Manhattan six - or was it seven or even eight months ago? - it had lived in systems which operated within a self-perpetuating reality; a series of enormous solipsisms, a tribute to the existential freedom of the land of free enterprise. But now I felt myself on the edge of a system of reality that might be perpetrated by factors entirely external to itself.... (Carter, Passion 167)

The functioning of each and every one of the worlds temporarily visited by Evelyn is plausibly explained. Thus, their reality is questioned only when compared and contrasted to the real world, as the readers know it.

\section{The City's Ex-Centric Spaces}

Writing about the construction of reality in Carter's earlier novels (e.g. Shadow Dance, Several Perceptions, Love), Mark O'Day claims that reality effects are achieved thanks to the manner in which

"art and life mingle so that life itself is often a form of art - in a variety of everyday, local private and public spaces. These include bedsits, flats and houses ... cafes and coffee bars, pubs and shops, auction rooms, museums, libraries, hospitals, the Zoo and the Labour Exchange, and outdoor locations like the streets, the park and the Down." (qtd. in Sage, Flesh 25)

Aidan Day, on the other hand, disagrees with the black and white division of Carter's novels into realist novels and magical realist ones, claiming that not even the mentioned Bristol trilogy reproduces reality in the purely mimetic manner. Instead, Day maintains that the link between the events in these novels and the real extratextual world is primarily figurative, which makes these novels, despite their superficial realism, to be read as allegories (Day 22), just like the rest of Carter's novels.

However, the places Marc O'Day founds his observation on are, indeed, part of traditional realist reality construction. In addition to these, Carter sets her novels in a range of ex-centric spaces that drastically question the perception of what is real and what is not. These spaces are 
ascribed the role of subverting social hierarchy and, as such, invoke the tradition of the Bakhtinian carnivalesque. In Nights at the Circus, the excentric spaces include a brothel, freak museum, variety show, prison, and circus; in Wise Children, the readers encounter music-halls, theatre and television, whereas The Infernal Desire Machines of Dr Hoffman features a travelling circus and a peepshow. In The Passion of New Eve, excentricity is attributed to diverse dystopian communities in the desert. Even snowy wastelands of Siberia, "a limbo to which we had no map" (Carter, Nights 265), with its forests that in circus procession awaken both claustrophobia and agoraphobia, represents one of the non-locations that is carnivalized. Providing "the focus for an alternative, carnivalesque worldview" (Peach 141), these ex-centric locations are firmly set within the realistically constructed cities in accordance with the narrative strategy of magical realism that emphasizes the coexistence of the ordinary with the uncanny. At the same time realistic and temporally firmly rooted, but also unrealistic and temporally elusive, they feature the margin that managed to carve out its own space within the very center that struggles to colonize it. As Sally Robinson notes, the marginalized world of the carnivalesque exists only in relation to the existing power structures and power centres (127) frequently embodied in the metropolis. The ex-centric spaces do not offer, by itself and in itself, the freedom of a de-centred pluralized world in which, in the words of Linda Hutcheon, only excentricity exists (Hutcheon, 1988). On the contrary, ex-centric and carnivalesque spaces must remain in a constant state of dialogue with power structures for the subversive nature of the carnivalesque to act within these structures. Judith Mayne warns that, if it is posited that the carnivalesque mode is by the definition a radical mode, and that it acts "from outside the dominant order other than from within it," "the extent to which the carnival may exist as a safety valve" that "guarantees the maintenance of the existing order" is obscured (qtd. in Peach 142). By placing the protagonists in such spaces, the author retains the context with which contemporary readers can identify, simultaneously enabling them to step outside of their ordered, predictable world (Michael 171).

The inhabitants of these spaces are traditionally marked as the Other, as those who do not belong to the everyday reality of traditional 
spaces. In relation to the position of the centre and the norm, the position of the Other is always marginalized and anti-authoritarian. One of the subversive aspects of magical realism lies in its reversal of the perspective, when the ordinary is presented as extraordinary and vice versa. The interplay of the centre and the margin, in terms of the spatial placement, makes such a reversal possible. The position of Otherness provides marginalized characters with a unique ex-centric perspective. In their alternative world, for example, freak shows, trapeze artists, and rubber men are a normal occurrence, not an exception to the rule. Thus, in The Infernal Desire Machines of Dr Hoffman, Desiderio, being mundane and "normal," finds himself in a travelling circus, where he acquires the aura of the exotic, precisely because he is the odd one out. In the world filled with the extraordinary performers, the ordinary becomes the Other:

I must admit that all my guests enchanted me and I, in return, enchanted them for, here, I had the unique allure of the norm. I was exotic precisely to the extent of my mundanity. The peep-show proprietor's nephew was a small businessman bankrupted by the catastrophe in the capital and all those freaks could not get enough of my accounts of the world of typewriters and telephones, flush toilets, tiled bathrooms, electric lights and mechanical appliances. (101)

Fredric Jameson argues that "the emergence of a new space and a new temporality" are among the goals of realism: the space is no longer depicted as something sacred (qtd. in Faris, "Scheherazade's Children" 173-174). Magical realism undoubtedly subverts this goal, making the space lose its distinct features, whereas time either stands still or loses its linear nature. The closed space of familiar London interiors in Nights at the Circus soon gives way to a range of spaces treated as cultural constructs in Sankt Petersburg and Siberia. Imagined as "a beautiful city that does not exist anymore," Sankt Petersburg is "this Sleeping Beauty ... yearning to burst through the present into the violence of that authentic history to which this narrative - as must by now be obvious! - does not belong" (Carter, Nights 110-111). Contrary to the city, Siberia is depicted as "unnatural spectacle" engulfed in "supernatural silence," "the vastness of nothing" through which the train moves towards "the extremities of nowhere" (Carter, Nights 232-233). Similarly, Evelyn, in The Passion of New 
Eve, finds himself in the desert, "the abode of enforced sterility, the dehydrated sea of infertility," "a landscape that matched the landscape" of his heart (Carter, Passion 40-41). If New York is depicted as "an alchemical city" where the residents experience shortage of water supplies while the whole country is short on oil, an underground city in the middle of the desert, in the middle of nowhere, represents a typical magical realist place "where contrarieties are equally true," "the place where contrarieties exist together" (Carter, Passion 16).

\section{The City as a Hybrid Reality}

The parallel existence of ordinary and ex-centric spaces in the city in Carter's magical realist novels is perceived as "a strange coherence among apparently different elements, spread out horizontally in time and space" (Faris, "Scheherazade's Children" 189). As such, the city supports an uncanny magical realist reality based on the mutually excluding but nevertheless coexisting elements. Such a reality is hybrid by its nature. A similar stance is expressed by Nicola Pitchford in her Tactical Readings: Feminist Postmodernism in the Works of Kathy Acker and Angela Carter, where Pitchford, writing about the suitability of contemporary cities' architecture for theorizing about postmodernism, posits that "the city is both imaginary and real" (45). Writing about the hybrid space in magical realism, Rawdon Wilson stipulates that simultaneous existence of the extraordinary and ordinary, as well as the interaction of the bizarre and prosaic, "the doubleness of conceptual codes" (210), give birth to the imminently hybrid nature of the reading experience.

Carter's hybrid cities provide a suitable location for the existence of such uncanny spaces, such as Tristesse's glass house in The Passion of New Eve - a house that itself appears to be an illusion. Also, the underground city in which Mother and her followers dwell, although artificially made, does not look unreal, but possesses "the unimpeachable quality of realism": "But it is a triumph of science and hardly anything about it is neutral, as if magic, there, masquerades as surgery in order to gain credence in secular age" (49).

A hybrid reality in a city is also exemplified through the mixing of the theatrical reality and everyday reality. In Wise Children, this theatrical 
reality extends to Hollywood, which itself is a part of the physical city, but also, symbolically, a dreamy domain of the unreal in which everything is equally possible. Reality and illusion mix not only on stage, but also on film sets:

And I no longer remember that set as set but as a real wood, dangerous, uncomfortable, with real, steel spines on the conkers and thorns on the bushes, but looking as if it were unreal and painted, and the bewildering moonlight spilled like milk in this wood, as if Hollywood were the name of the enchanted forest where you lose yourself and find yourself, again; the wood that changes you; the wood where you go mad; the wood where the shadows live longer than you do. (Carter, Wise Children 157-158)

The unreal/ real perspective is additionally complicated here: the protagonist sees what is unreal as being real, but at the same time he believes that this is just a pretence. Such reality is at the same time plausible and believable, but also "theatrically conventional" (Sherman 33).

In The Infernal Desire Machines of Dr Hoffman, the reality upstaged by the eponymous hero is not objective, to start with - rather, it exists as an agreement on what is real and what is not. Such a reality is only one possible interpretation of the reality that does not allow other realities to exist. The embodiment of a rigid outlook on reality is found in the character of Minister of Determination:

He believed the criterion of reality was that a thing was determinate and the identity of a thing lay only in the extent to which it resembled itself ... He believed that the city - which he took as a microcosm of the universe - contained a finite set of objects and a finite set of their combinations and therefore a list could be made of all possible distinct forms which were logically viable." (Carter, Infernal Desire 23-24)

In these hybrid cities reality is constructed, rather than existing on its own. However, if reality is just a construct, then it must be possible to deconstruct it: after Dr Hoffman unleashes the imagination of the city's residents, the number of possible realities multiplies exponentially. Each of these realities is highly subjective. However, this fact does not make it any less real. The city, as a sum of all these realities, transforms into an alternative world in which imagination is no longer held within a person, 
that is to say within the city's residents, but is let loose, free to exist as "actualized desire" (Carter, Infernal Desire 11).

The hybridity of Carter's magical realist works is possibly most prominent on the temporal plane. In Carter's hybrid cities, the past and the present often intertwine to such an extent that the cities themselves have to be spatio-temporally renegotiated and reconstructed. As a consequence, the characters frequently find themselves pacing the streets that belong to some previous times, the streets they themselves never walked on before. The hybrid cities in Carter's novels serve to subvert the boundaries between the contrasted notions in the binary pairs of the present vs. the past, the real vs. the unreal, the denominator vs. the denominated. However, the "magical" elements introduced into the real cities are not meant to divert the readers' attention away from concrete social and political problems that the author tackles in her feminist-postmodernist fiction. While this is undoubtedly an aspect of Carter's deployment of magical realism, the hybrid cities in her fiction can be interpreted not only as the trademark of this narrative mode, but also as pertaining to the general tendency of contemporary British authors to reinvent the city, underscoring its "artificial nature" (Groes 2).

\section{The City and Utopia}

Agreeing with Fredric Jameson, Wendi B. Faris reads magical realism as a descendant of romance that allows for greater narrative heterogeneity and greater freedom from "oppressive realistic representation" of mimetic realism (Faris, Ordinary Enchantments 159). The difference between the two modes Faris sees in the fact that romance creates "a nostalgic or utopian harmony" and, as such, "is ultimately not politically progressive" (159). Indeed, Carter does not create the city as a utopian space. Even alternative communities existing outside of the city are rarely presented in this manner. In The Passion of the New Eve, the underground city in the desert harbours a matriarchal community whose ultimate ruler and, simultaneously, ultimate symbol is Mother. However, this matriarchal city, with an extremely limited outlook on life, borders on militant philosophy. The matriarchy with its wild celebration of feminine myths is 
being satirized and parodied, and the "construction of Beulah" is ultimately seen as "a construction determined by the masculine" (Day 116). The other end of the spectrum of the imaginary communities in this novel features the desert hermit's community, none the more progressive. Additionally, the community of soldier-boys serving Christianity is not seen as a utopian goal, and neither is the society of the potentially liberated America. Although in Desiderio's city reality is disbanded, the world of illusions is not considered to be an ideal model of existence, and the same applies to various communities Desiderio encounters during his travels. The utter freedom from reason is depicted as dangerous, and the real enemy is to be found not outside the city walls, but within - within the city and within human imagination. Freeing human imagination is, paradoxically, the path to enslavement, not liberation: "But, if the city was in a state of siege, the enemy was inside the barricades, and lived in the minds of each of us" (Carter, Infernal Desire 12).

The only semblance of utopia can be found on a micro level, at some of the already mentioned ex-centric spaces in the novels Nights at the Circus and Wise Children. Several characters in Nights at the Circus talk about Utopia or even attempt to put the idea into practice. Images of life at Ma Nelson's house invoke a female-only utopian community: "Let me tell you that it was a wholly female world within Ma Nelson's door. Even the dog that guarded it was a bitch and all the cats were females..." (Carter, Nights 42). There were no fights, no quarrels, and no malice, since "life within these walls was governed by a sweet and loving reason" (Carter, Nights 42). In this unofficial female academy, every girl possesses a talent or a skill - such as shorthand typing, playing flute or book reading - which are honed in the daytime. However, with the onset of night, this advancement of individual talents gives way to the practices of satisfying male desire, since the academy turns from an autonomous female world into a brothel, a morally problematic and highly stereotyped component of the male world. After the brothel goes out of business, each girl follows her own path in life - all of them, however, pick professions that drastically diverge from the traditionally defined female roles. Whether they run a boarding house or own a typist office, they all choose professions suitable for a "New Woman" - an achievement that might fall 
under the heading of a utopia, albeit modified. Mignon similarly overcomes patriarchal limitations and expectations based on the idea of traditional female roles, and finds her true self living with Princess of Abyssinia, after having been rescued by women: "'The cruel sex threw her away like a soiled glove,' said Fevvers, 'but us girls 'ave gone and sent her to the cleaner's!,' Lizzie concluded triumphantly" (Carter, Nights 181).

Another semblance of utopia is found in the third part of the novel, when female convicts in Siberia make a silent pact with the female wardens and together turn on Countess P., who keeps them in a prison organized according to the principles of Foucault's panopticon. The panopticon layout of the prison enables the power centre to exert the absolute control over the prisoners, but - working both ways - allows the prisoners the same level of control over the power centre. After Olga Alexandrovna dares to get in touch with one of the wardens, the events unroll following the domino effect, culminating in the joint prison break. To the women who are about to establish a female utopia in Siberian taiga, the vast snow-covered landscape seems promising enough: "The white world around them looked newly made, a blanket sheet of white paper on which they could inscribe whatever future they wished" (256257). Contrary to Nights at the Circus's female characters whose utopia appears to be either successfully implemented or holds the promise of a future success, male characters are nowhere near achieving a concrete utopian life. Although Fugitive attempted to "bring Utopia one step further" (Carter, Nights 169) by blowing up a copper-shop, he ended up in Siberia, where Lizzy's initial admiration is soon replaced by contempt towards him.

The utopian life in the Chance twins' house in Wise Children again centres on female characters, since it is this house that provided shelter to the women who need sanctuary from the patriarchal world of false dichotomies and hypocrite standards. Although located on the wrong bank of the river Thames, in the wrong part of London, on the wrong end of economic and social spectrum, their home is a refuge, first for Dora and Nora's mother, then for themselves, and subsequently for a range of shunned women - Our Cyn, Tiffany and Lady Atalanta. 


\section{Conclusions}

Reality in Carter's magical realist novels is depicted through the deployment of numerous picturesque details that correspond to the readers' experiential reality, differentiating such a world from fantasies, fairy tales, and allegories. Although the magical realist fictional world is akin to the one outside of the fictional reality, the mode's strategy still differs from that of traditional realism due to the absence of a purely mimetic role. Magical elements introduced into this real framework do not disrupt the plausibility of the work, nor do they disrupt its unity. As an exponent of such reality, the city is a narrative construct in which elements of colonial history, post-empire present, and possibly apocalyptic future fall together as if they were kaleidoscope pieces. The geography of the city is not just about the territory, but also about violence, socio-political, financial, and cultural demarcation lines and stereotypes of identity. It is no wonder, then, that frequently, in Carter's fiction, serving the programmatic purpose of her self-professed "demythologizing business," the city's structures need to be destructed in order for both the protagonists and the world in general to be able to start over. However, as with the carnival and the carnivalesque, nothing ever changes for good - exploded buildings in Night at The Circus land on "earth again in exactly the same places where they had stood before" (Carter, Nights 151). The existence of utopian features only in some of the ex-centric spaces in the city, however, tallies with her ideological position and her artistic philosophy. Her novels are not meant to imply "that carnival and fantasy can suffice nor suggests that rationalism and critique be eschewed" (Gasiorek 135). She views the novel as "a composite form in which both kinds of discourse supplement one another, allowing the writer a fuller apprehension of reality" (Gasiorek 135). The aim of magical realism in Carter's novels is not to forever disrupt the categories of facts and fiction, reality and illusion, but to question and subvert the hierarchical opposition on which the distinction is founded, revealing its fallacy. The multiplicity of perspectives exemplified in the city she constructs facilitates this and lies at the centre of her political and feminist engagement. 


\section{Notes:}

${ }^{\mathrm{i}}$ Despite the continuous and overwhelming debate on the proper categorization of magical realism - including categories such as a literary genre, an artistic movement, and a wider cultural category - I choose to approach it as a universal narrative mode that, in the words of Amaryll Chanady, "defies limitations of geography, generation and language“ (qtd. in Schroeder 13) and, as such, can be suitably appropriated by diverse literary and cultural movements and poetics (such as, for example, postmodernism, postcolonialism or (post)feminism) (Muždeka 29). More on this in Nina Muždeka, Magical Realism in the Novels of Angela Carter (Magijski realizam u romanima Andžele Karter), Novi Sad: Filozofski Fakultet, 2017, 29-32.

\section{Works Cited}

Bradfield, Scott. "Remembering Angela Carter." The Review of Contemporary Fiction 14:3 (1994): 91.

Carter, Angela. Expletives Deleted. 1992. London: Vintage. 1993.

---. The Infernal Desire Machines of Doctor Hoffman. 1972. London: Penguin, 1982.

---. The Magic Toyshop. 1967. London: Virago P, 2006.

---. "My Maugham Award." Shaking a Leg: Collected Journalism and Writing. London: Chatto, 1997. 203-204.

---. Nights at the Circus. 1984. London: Vintage, 2006.

---. The Passion of New Eve. 1977. London: Virago P, 1998.

---. Wise Children. Toronto: Little, 1991.

Day, Aidan. Angela Carter: The Rational Glass. Manchester: Manchester UP, 1998.

Faris, Wendy B. Ordinary Enchantments: Magical Realism and the Remystification of Narrative. Nashville: Vanderbilt UP, 2004.

---. "Scheherazade's Children: Magical Realism and Postmodern Fiction." Magical Realism: Theory, History, Community. Ed. Lois Parkinson Zamora and Wendy B. Faris. Durham: Duke UP, 1995. 163-190.

Gasiorek, Andrzej. Post-War British Fiction: Realism and After. London: Arnold, 1995.

Groes, Sebastian. The Making of London: London in Contemporary Literature. Basingstoke: Palgrave Macmillan, 2011.

Haffenden, John. Novelists in Interview. London: Methuen, 1985.

Hegerfeldt, Anne. "Contentious Contributions: Magical Realism Goes British." Janus Head 5.2 (2002): 62-86.

---. Lies that Tell the Truth: Magic Realism Seen through Contemporary Fiction from Britain. Amsterdam: Rodopi, 2005.

Michael, Magali Cornier. Feminism and Postmodern Impulse: Post-World War II Fiction. Albany: State U of New York P, 1996. 
Muždeka, Nina. Magical Realism in the Novels of Angela Carter (Magijski realizam u romanima Andžele Karter). Novi Sad: Filozofski Fakultet, 2017.

Peach, Linden. Angela Carter. London: Macmillan P, 1998.

Pitchford, Nicola. Tactical Readings: Feminist Postmodernism in the Novels of Kathy Acker and Angela Carter. London: Associated UP, 2002.

Robinson, Sally. Engendering the Subject: Gender and Self-Representation in Contemporary Women's Fiction. Albany: State U of New York P, 1991.

Sage, Lorna. Flesh and the Mirror: Essays on the Art of Angela Carter. London: Virago, 1994.

---. "The Savage Sideshow: A Profile of Angela Carter." The New Review 4 (1977): 51-56.

Schroeder, Shannin. Rediscovering Magical Realism in the Americas. Westport: Praeger Publishers, 2004.

Sherman, Delia. "Grand Illusionist." The Women's Review of Books 9.10-11 (1992): 33.

"The Somerset Maugham Award." The Society of Authors Awards. Web. 1 Feb. 2020.

Stewart, Melissa. "Roads of 'Exquisite Mysterious Muck': The Magical Journey through the City in William Kennedy's Ironweed, John Cheever's 'The Enormous Radio,' and Donald Barthelme's 'City Life'." Magical Realism: Theory, History, Community. Ed. Lois Parkinson Zamora and Wendy B. Faris. Durham: Duke UP, 1995. 477 - 496.

Wilson, Rawdon. "The Metamorphoses of Fictional Space: Magical Realism." Magical Realism: Theory, History, Community. Ed. Lois Parkinson Zamora and Wendy B. Faris. Durham: Duke UP, 1995. 209 - 234. 